\title{
Weed Control in White Bean with Pendimethalin Applied Preplant Followed by Postemergence Broadleaved Herbicides
}

\author{
N. Soltani*,1, R.E. Nurse ${ }^{2}$, C. Shropshire ${ }^{1}$ and P.H. Sikkema ${ }^{1}$ \\ ${ }^{1}$ University of Guelph Ridgetown Campus, Ridgetown, Ontario, Canada, NOP 2C0; ${ }^{2}$ Agriculture and Agri-Food \\ Canada, Harrow, Ontario, Canada, NOR 1 G0
}

\begin{abstract}
Field trials were conducted over a three-year period (2009 to 2011) to evaluate the efficacy of pendimethalin preplant-incorporated (PPI), bentazon, fomesafen, bentazon plus fomesafen, or halosulfuron applied postemergence (POST) and the sequential application of pendimethalin applied PPI followed by bentazon, fomesafen, bentazon plus fomesafen or halosulfuron applied POST in white bean in Ontario. There was minimal effect on seed moisture content of white bean with the herbicides evaluated. Pendimethalin provided $97 \%$ control of $A$. retroflexus, $9 \%$ of $A$. artemisiifolia, $90 \%$ of $C$. album, $12 \%$ of $S$. arvensis, and $96 \%$ of S.viridis. Bentazon, fomesafen, bentazon plus fomesafen, and halosulfuron applied POST provided as much as $93 \%$ control of $A$. retroflexus, $86 \%$ control of $A$. artemisiifolia, $72 \%$ control of C. album, $99 \%$ control of $S$. arvensis, and $29 \%$ control of $S$. viridis. The sequential application of pendimethalin applied PPI followed by bentazon, fomesafen, bentazon plus fomesafen, and halosulfuron applied POST provided 100\% control of $A$. retroflexus, $87 \%$ control of $A$. artemisiifolia, $90 \%$ control of $C$. album, $100 \%$ control of $S$. arvensis, and $95 \%$ control of $S$.viridis, respectively. White bean yield generally reflected the level of weed control.
\end{abstract}

Keywords: Bentazon; density; dry weight; fomesafen; halosulfuron; navy bean; pendimethalin; yield

\section{INTRODUCTION}

Canada is one of the largest white bean (Phaseolus vulgaris L.) producing countries in the world [1]. In 2010, Ontario growers produced $82,600 \mathrm{MT}$ of white bean with a farm-gate value of $\$ 55$ million on 34,400 hectares [2]. White bean is a short season crop with short physical stature and is not a strong competitor with weeds. Weed interference can result in as much as $70 \%$ yield losses in white bean $[3,4]$. Weeds also interfere with harvest operations and may stain white bean, resulting in reduced market value [5-7]. Therefore weed management is very important for profitable white bean production. Identification of weed management strategies that provide consistent effective broad spectrum weed control is needed to make white bean growers competitive in the global market.

Pendimethalin is a dinitroaniline herbicide that controls annual grasses including barnyardgrass (Echinochloa crusgalli (L.) Beauv.), smooth crabgrass (Digitaria ischaemum (Schreb) Muhl.), large crabgrass (Digitaria sanguinalis (L.) Scop), fall panicum (Panicum dichotomiflorum Michx., giant foxtail (Setaria faberii Herrm.), S. viridis, and yellow foxtail (Setaria glauca (L.) Beauv.). Pendimethalin can also control certain annual broadleaved weeds such as common lamb'squarters (Chenopodium album L.) and redroot pigweed (Amaranthus retroflexus L.) including acetolactate synthase and triazine-resistant biotypes $[8,9]$.

*Address correspondence to this author at the University of Guelph Ridgetown Campus, Ridgetown, Ontario, NOP 2C0, Canada;

Tel: 519-674-1500; Fax: 519-674-1600;

E-mail: soltanin@uoguelph.c
Bentazon is a benzothiadiazole postemergence (POST) herbicide that can control broadleaved weeds including Chenopodium album, purslane (Portulaca oleracea L.), wild radish (Raphanus raphanistrum), hairy galinsoga (Galinsoga ciliata), common groundsel (Senecio vulgaris), jimsonweed (Datura stramonium L.), velvetleaf (Abutilon theophrasti Medic.), ladysthumb (Polygonum persicaria L.), wild mustard (Sinapis arvensis L.), cocklebur (Xanthium strumarium L.), shepherdspurse (Capsella bursa-pastoris) and common chickweed (Stellaria media) including acetolactate synthase and triazine-resistant biotypes [8,9].

Fomesafen is a diphenyl ether herbicide that can control broadleaved weeds such as Sinapis arvensis, Amaranthus retroflexus, Ambrosia artemisiifolia, Polygonum persicaria, Xanthium strumarium and Solanum spp. [8,9]. Fomesafen in tank mix combination with bentazon can provide improved control of broadleaved weeds such as Amaranthus, Ambrosia, Solanum and Polygonum convolvulus [8,9].

Halosulfuron is a sulfonylurea herbicide that controls several broadleaved weeds that occur in Ontario such as Amaranthus retroflexus, Abutilon theophrasti, Polygonum persicaria, Xanthium strumarium, Sinapis arvensis, and nutsedge species (Cyperus spp.), including triazine resistant biotypes [9].

Combination of graminicide herbicides with broadleaved herbicides has been shown to improve the level of weed control in dry bean [10]. However, there is little information on the relative efficacy of pendimethalin applied PPI followed by POST herbicides such as bentazon, fomesafen, bentazon plus fomesafen or halosulfuron in white bean under Ontario environmental conditions. 
Table 1. Redroot pigweed control (\%) 4 and 8 WAA, density and dry weight with various herbicides in white bean at Exeter, ON from 2009 to 2011. Means followed by the same letter (a-e) within a column are not significantly different according to Fisher's Protected LSD at $\mathbf{P}<\mathbf{0 . 0 5}$.

\begin{tabular}{|c|c|c|c|c|c|c|c|c|c|c|c|c|}
\hline \multirow{4}{*}{ Treatment } & \multirow{2}{*}{\multicolumn{2}{|c|}{ Rate }} & \multicolumn{6}{|c|}{ Weed control } & & & & \\
\hline & & & \multirow{2}{*}{\multicolumn{2}{|c|}{4 WAA }} & \multicolumn{4}{|c|}{8 WAA } & & & & \\
\hline & PPI & POST & & & & & & & \multicolumn{2}{|c|}{ Density } & \multicolumn{2}{|c|}{ Dry weight } \\
\hline & \multicolumn{2}{|c|}{ g ai ha ${ }^{-1}$} & \multicolumn{4}{|c|}{$-\%$} & & & \multicolumn{2}{|c|}{ Plants $\mathbf{m}^{-2}$} & \multicolumn{2}{|c|}{$\mathrm{g} \mathrm{m}^{-2}$} \\
\hline Weedy check & - & - & 0 & $\mathrm{f}$ & 0 & $\mathrm{c}$ & 0 & $\mathrm{~d}$ & 29.2 & $\mathrm{f}$ & 84.4 & $\mathrm{e}$ \\
\hline Pendimethalin & 1080 & - & 95 & $\mathrm{bc}$ & 98 & a & 98 & $\mathrm{ab}$ & 0.9 & abcd & 0.9 & $\mathrm{ab}$ \\
\hline Bentazon & - & 1080 & 54 & $\mathrm{e}$ & 76 & $\mathrm{~b}$ & 55 & $\mathrm{c}$ & 4.6 & $\mathrm{e}$ & 12.0 & $\mathrm{~d}$ \\
\hline Fomesafen & - & 240 & 93 & $\mathrm{bc}$ & 99 & $\mathrm{a}$ & 94 & $\mathrm{~b}$ & 0.6 & $a b c$ & 0.7 & $\mathrm{ab}$ \\
\hline Pendimethalin $\mathrm{fb}$ fomesafen ${ }^{\mathrm{b}}$ & 1080 & 240 & 99 & $a b$ & 100 & $a$ & 99 & $\mathrm{ab}$ & 0.2 & $a b c$ & 0 & $\mathrm{a}$ \\
\hline $\begin{array}{l}\text { Pendimethalin fb bentazon }+ \\
\text { fomesafen }\end{array}$ & 1080 & $840+140$ & 97 & $a b$ & 99 & $\mathrm{a}$ & 98 & $a b$ & 0.1 & $\mathrm{ab}$ & 0.1 & $\mathrm{ab}$ \\
\hline $\begin{array}{l}\text { Pendimethalin } \mathrm{fb} \\
\text { halosulfuron }^{\mathrm{c}}\end{array}$ & 1080 & 35 & 98 & $\mathrm{ab}$ & 100 & $\mathrm{a}$ & 93 & $\mathrm{~b}$ & 0.4 & $a b c$ & 0.5 & $\mathrm{ab}$ \\
\hline \multirow{2}{*}{ Contrasts } & \multicolumn{2}{|c|}{ PPI vs PPI fb POST } & \multicolumn{2}{|c|}{ NS } & \multicolumn{2}{|c|}{ NS } & \multicolumn{2}{|c|}{ NS } & \multicolumn{2}{|c|}{ NS } & \multicolumn{2}{|c|}{ NS } \\
\hline & \multicolumn{2}{|c|}{ POST vs PPI fb POST } & \multicolumn{2}{|c|}{$* *$} & \multicolumn{2}{|c|}{$* *$} & \multicolumn{2}{|c|}{$* *$} & \multicolumn{2}{|c|}{$* *$} & \multicolumn{2}{|c|}{$* *$} \\
\hline
\end{tabular}

Abbreviations: DAA, days after POST application; fb, followed by; NS, not significant; POST, postemergence; PPI, preplant incorporated.

Included Turbocharge at $0.5 \% \mathrm{v} / \mathrm{v}$.

Included non-ionic surfactant at $0.25 \% \mathrm{v} / \mathrm{v}$.

Significance at $\mathrm{P}<0.05$ and $\mathrm{P}<0.001$ denoted by * and **, respectively.

The objectives of this study were to evaluate the efficacy of pendimethalin applied PPI, bentazon, fomesafen, bentazon plus fomesafen or halosulfuron applied POST, and the sequential application of pendimethalin applied PPI followed by the POST application of bentazon, fomesafen, bentazon plus fomesafen or halosulfuron in white bean.

\section{MATERIALS AND METHODS}

Field studies were conducted in 2009, 2010 and 2011 at the Huron Research Station, Exeter, Ontario. The soil was a Brookston loam/clay loam (Orthic Humic Gleysol, mixed, mesic, and poorly drained) with $44 \%$ sand, $33 \%$ silt, $23 \%$ clay, $4.1 \%$ organic matter and $\mathrm{pH} 7.9$ in $2009,32 \%$ sand, $40 \%$ silt, $28 \%$ clay, $4.5 \%$ organic matter and $\mathrm{pH} 7.8$ in 2010 , and $35 \%$ sand, $43 \%$ silt, $22 \%$ clay, $4.0 \%$ organic matter and pH 7.8 in 2011. Seedbed preparation at all sites consisted of autumn moldboard plowing followed by two passes with a field cultivator in the spring.

The experiment was arranged in a randomized block design with treatments replicated four times. Treatments are listed in Table 1. Each plot was $3.0 \mathrm{~m}$ wide and $10 \mathrm{~m}$ long and consisted of four rows of 'T9905' white bean spaced $0.75 \mathrm{~m}$ apart. White bean was planted at a rate of 250,000 seeds $\mathrm{ha}^{-1}$ in late May to early June of each year.
Herbicide treatments were applied using a $\mathrm{CO}_{2-}^{-}$ pressurized backpack sprayer calibrated to deliver $200 \mathrm{~L} \mathrm{ha}^{-1}$ at $240 \mathrm{kPa}$. The boom was $1.5 \mathrm{~m}$ wide with four ultra-low drift nozzles (ULD120-02, Hypro, New Brighton, MN) spaced $50 \mathrm{~cm}$ apart. Preplant incorporated herbicides were applied one day before planting and were immediately incorporated into the soil with two passes (in opposite directions) of an S-tine cultivator with rolling basket harrows. The POST herbicide applications were made to 2-3 trifoliate leaf beans. Weed free plots were maintained weed free by cultivation and hand hoeing as required.

White bean injury and weed control were visually estimated on a scale of 0 (no injury/control) to $100 \%$ (complete plant death) at 1,4 and 8 weeks after the postemergence application (WAA), and 4 and 8 WAA, respectively. Weed density and dry weight were evaluated at 8 WAA by counting and cutting plants at the soil surface in two $0.5 \mathrm{~m}^{2}$ quadrats per plot and separating by species. Plants were dried at $60{ }^{\circ} \mathrm{C}$ to a constant moisture and then weighed. White bean was considered mature when $90 \%$ of the pods in the weed-free check had turned from green to a golden colour. Beans were harvested from each plot with a small plot combine, weight and seed moisture content were recorded, and yields were adjusted to $18 \%$ moisture. 
Data were analyzed using PROC MIXED in SAS 9.2 [11]. Herbicide treatment was considered a fixed effect, while environment (year), environment by treatment interaction, and replicate nested within environment were considered random effects. Significance of fixed effects were tested using F-tests and random effects were tested using a Z-test of the variance estimate. Environments were combined for a given variable if the environment by treatment interaction was not significant. The UNIVARIATE procedure was used to test data for normality and homogeneity of variance. Any treatment assigned a value of zero (weedy check for injury and weed control; weed-free check for injury, weed density and dry weights) was excluded from the analysis. However, all values were compared independently to zero to evaluate treatment differences with the weedy and/or weed-free checks. To satisfy the assumptions of the variance analyses, weed control at both evaluations for Amaranthus retroflexus and Ambrosia artemisiifolia, and at 8 WAA only for Chenopodium album, Setaria viridis, and Sinapsis arvensis were arcsine square root transformed, and all weed density and dry weights were log transformed. Treatment comparisons were made using Fisher's Protected LSD at a level of $\mathrm{P}<0.05$. Additionally, two contrasts were run to determine if there was a benefit to applying i) a postemergence broadleaved herbicide after pendimethalin compared to pendimethalin alone, and ii) pendimethalin prior to a postemergence broadleaved herbicide compared to a broadleaved herbicide alone. Data compared on the transformed scale were converted back to the original scale for presentation of results.

\section{RESULTS AND DISCUSSION}

\section{Crop Injury}

Although some injury was significant, none of the values were above $5 \%$ at $1 \mathrm{WAA}$ and were even lower (and not significant) at 4 and 8 WAA (data not shown). There was no effect on seed moisture content (maturity) of white bean with the herbicide treatments evaluated (data not shown).

\section{Weed Control}

Dominant weeds in this study as determined by quantification and qualification of non-treated control plots included Amaranthus retroflexus, Ambrosia artemisiifolia, Chenopodium album, Sinapsis arvensis and Setaria viridis

\section{Amaranthus Retroflexus}

Pendimethalin applied PPI at $1080 \mathrm{~g}$ ai $\mathrm{ha}^{-1}$ provided excellent (95-98\%) control of $A$. retroflexus and reduced density $97 \%$ and dry weight $99 \%$ compared to the weedy check (Table 1). Bentazon, fomesafen, bentazon plus fomesafen or halosulfuron applied POST controlled $A$. retroflexus as much as $76,99,98$, and $100 \%$, reduced density $84,98,93$, and $88 \%$ and reduced dry weight $86,99,98$, and $93 \%$, respectively (Table 1). The sequential application of pendimethalin applied PPI followed by bentazon, fomesafen, bentazon plus fomesafen or halosulfuron applied POST controlled $A$. retroflexus as much as $100,100,99$, and $100 \%$, reduced density $95,99,100$, and $99 \%$ and reduced dry weight 96, 100, 100, and 99\%, respectively (Table 1). Or- thogonal contrasts indicated that there was no significant difference between pendimethalin PPI compared to the sequential application of pendimethalin PPI followed by POST herbicides for the control of $A$. retroflexus (Table 1). However, the sequential application of pendimethalin PPI followed by POST herbicides provided better control of $A$. retroflexus than the POST herbicides alone.

\section{Ambrosia Artemisiifolia}

Pendimethalin applied PPI at $1080 \mathrm{~g}^{\text {ai }} \mathrm{ha}^{-1}$ provided minimal (8-10\%) control of $A$. artemisiifolia and did not reduce density and dry weight of $A$. artemisiifolia compared to the weedy check (Tables 2). Bentazon, fomesafen, bentazon plus fomesafen or halosulfuron applied POST controlled A. artemisiifolia as much as $51,98,94$, and $99 \%$, reduced density as much as $12,100,100$, and $100 \%$ and reduced dry weight $43,100,100$, and $100 \%$, respectively (Table 2 ). The sequential application of pendimethalin applied PPI followed by bentazon, fomesafen, bentazon plus fomesafen or halosulfuron applied POST controlled $A$. artemisiifolia as much as $60,98,95$, and $96 \%$, reduced density $45,100,91$, and $100 \%$ and reduced dry weight as much as $51,100,97$, and $100 \%$, respectively (Table 2). Orthogonal contrasts indicated that the sequential application of pendimethalin PPI followed by POST herbicides provided better control of $A$. artemisiifolia compared to the pendimethalin applied PPI alone (Table 2). However, the sequential application of pendimethalin PPI followed by POST herbicides did not provide a benefit in controlling A. artemisiifolia compared to the POST herbicides alone.

\section{Chenopodium Album}

Pendimethalin applied PPI at $1080 \mathrm{~g}^{\mathrm{ai} \mathrm{ha}} \mathrm{ha}^{-1}$ provided 82$97 \%$ control of C. album and reduced density $89 \%$ and dry weight $97 \%$ compared to the weedy check (Tables 3 ). Bentazon, fomesafen, bentazon plus fomesafen or halosulfuron applied POST controlled C. album as much as 90, 75, 85, and $38 \%$, reduced density $90,68,85$, and $0 \%$ and reduced dry weight $94,48,84$, and $0 \%$, respectively (Table 3 ). The sequential application of pendimethalin applied PPI followed by bentazon, fomesafen, bentazon plus fomesafen or halosulfuron applied POST controlled C. album 99, 87, 92, and $83 \%$, reduced density $91,81,91$, and $81 \%$ and reduced dry weight 94, 76, 90, and 36\%, respectively (Table 3). Orthogonal contrasts indicated that the sequential application of pendimethalin PPI followed by POST herbicides provided a benefit in controlling C. album compared to the POST herbicides alone (Table $\mathbf{3}$ ).

\section{Sinapsis Arvensis}

Pendimethalin applied PPI at $1080 \mathrm{~g}^{\text {ai }} \mathrm{ha}^{-1}$ provided minimal $(0-23 \%)$ control of $S$. arvensis and did not reduce density and dry weight compared to the weedy check (Tables 4). Bentazon, fomesafen, bentazon plus fomesafen or halosulfuron applied POST controlled S. arvensis as much as 97, 100,100 , and $100 \%$, reduced density $98,100,100$, and $100 \%$ and reduced dry weight $100,100,100$, and $100 \%$, respectively (Table 4). The sequential application of pendimethalin applied PPI followed by bentazon, fomesafen, bentazon plus fomesafen or halosulfuron applied POST controlled $S$. arvensis $100 \%$ and reduced density and dry weight $100 \%$ compared to the weedy check (Table 4). Orthogonal 
Table 2. Visual estimates of percent common ragweed control 4 and 8 WAA, density and dry weight with various herbicides in white bean at Exeter, ON from 2009 to 2011. Means followed by the same letter (a-e) within a column are not significantly different according to Fisher's Protected LSD at $\mathbf{P}<0.05$.

\begin{tabular}{|c|c|c|c|c|c|c|c|c|c|c|c|c|c|c|}
\hline \multirow{4}{*}{$\begin{array}{l}\text { Treatment } \\
\text { Weedy check }\end{array}$} & \multicolumn{2}{|c|}{ Rate } & \multicolumn{4}{|c|}{ Weed control } & \multicolumn{4}{|c|}{ Density } & \multicolumn{4}{|c|}{ Dry weight } \\
\hline & PPI & POST & \multicolumn{2}{|c|}{4 WAA } & \multicolumn{2}{|c|}{8 WAA } & 20 & & \multicolumn{2}{|c|}{ 2010-11 } & \multicolumn{2}{|c|}{2009} & \multicolumn{2}{|c|}{ 2010-11 } \\
\hline & \multicolumn{2}{|c|}{ g ai ha ${ }^{-1}$} & \multicolumn{4}{|c|}{$\%$} & \multicolumn{4}{|c|}{ Plants $\mathrm{m}^{-2}$} & \multicolumn{4}{|c|}{$\mathrm{g} \mathrm{m}^{-2}$} \\
\hline & - & - & 0 & $\mathrm{e}$ & 0 & $\mathrm{e}$ & 19.5 & $\mathrm{c}$ & 3.3 & de & 19.2 & $\mathrm{c}$ & 23.0 & $\mathrm{~cd}$ \\
\hline Weed-free check & - & - & 100 & $\mathrm{a}$ & 100 & $\mathrm{a}$ & 0 & $\mathrm{a}$ & 0 & $\mathrm{a}$ & 0 & $\mathrm{a}$ & 0 & $\mathrm{a}$ \\
\hline Pendimethalin & 1080 & - & 8 & d & 10 & d & 58.6 & d & 6.6 & e & 142.9 & d & 84.4 & $\mathrm{~d}$ \\
\hline Bentazon & - & 1080 & 50 & $\mathrm{c}$ & 51 & $\mathrm{c}$ & 18.4 & $\mathrm{c}$ & 2.9 & cde & 80.5 & d & 13.2 & bcd \\
\hline Fomesafen & - & 240 & 95 & $\mathrm{~b}$ & 98 & $\mathrm{ab}$ & 0 & $\mathrm{a}$ & 0.4 & $\mathrm{ab}$ & 0 & $\mathrm{a}$ & 0.8 & $\mathrm{ab}$ \\
\hline Bentazon + fomesafen & - & $840+140$ & 92 & $\mathrm{~b}$ & 94 & $\mathrm{~b}$ & 1.8 & $\mathrm{~b}$ & 0 & $\mathrm{a}$ & 2.1 & $\mathrm{~b}$ & 0 & $\mathrm{a}$ \\
\hline Halosulfuron & - & 35 & 98 & $a b$ & 99 & $a b$ & 0 & $\mathrm{a}$ & 0.1 & $\mathrm{a}$ & 0 & $\mathrm{a}$ & 0 & $\mathrm{a}$ \\
\hline Pendimethalin fb bentazon & 1080 & 1080 & 60 & $\mathrm{c}$ & 53 & $\mathrm{c}$ & 36.5 & $\mathrm{~cd}$ & 1.8 & bcd & 183.2 & d & 11.2 & bed \\
\hline Pendimethalin $\mathrm{fb}$ fomesafen ${ }^{\mathrm{b}}$ & 1080 & 240 & 96 & $a b$ & 98 & $a b$ & 0.5 & $a b$ & 0 & $\mathrm{a}$ & 0.1 & $a b$ & 0 & $\mathrm{a}$ \\
\hline $\begin{array}{l}\text { Pendimethalin fb bentazon }+ \\
\text { fomesafen }\end{array}$ & 1080 & $840+140$ & 90 & $\mathrm{~b}$ & 95 & $\mathrm{~b}$ & 1.8 & $\mathrm{~b}$ & 0.7 & $\mathrm{abc}$ & 2.7 & $\mathrm{~b}$ & 0.6 & $\mathrm{ab}$ \\
\hline $\begin{array}{l}\text { Pendimethalin fb } \\
\text { halosulfuron }^{c}\end{array}$ & 1080 & 35 & 94 & $\mathrm{~b}$ & 96 & $\mathrm{~b}$ & 0 & $\mathrm{a}$ & 1.0 & abcd & 0 & $\mathrm{a}$ & 1.3 & $a b c$ \\
\hline \multirow{2}{*}{ Contrasts } & \multicolumn{2}{|c|}{ PPI vs PPI fb POST } & \multicolumn{2}{|c|}{$* *$} & \multicolumn{2}{|c|}{$* *$} & \multicolumn{2}{|c|}{$* *$} & \multicolumn{2}{|c|}{ 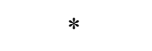 } & \multicolumn{2}{|c|}{$* *$} & \multicolumn{2}{|c|}{$*$} \\
\hline & \multicolumn{2}{|c|}{ POST vs PPI fb POST } & \multicolumn{2}{|c|}{ NS } & \multicolumn{2}{|c|}{ NS } & \multicolumn{2}{|c|}{ NS } & \multicolumn{2}{|c|}{ NS } & \multicolumn{2}{|c|}{ NS } & \multicolumn{2}{|c|}{ NS } \\
\hline
\end{tabular}

Abbreviations: DAA, days after POST application; fb, followed by; NS, not significant; POST, postemergence; PPI, preplant incorporated

Included Turbocharge at $0.5 \% \mathrm{v} / \mathrm{v}$.

Included non-ionic surfactant at $0.25 \% \mathrm{v} / \mathrm{v}$.

Significance at $\mathrm{P}<0.05$ and $\mathrm{P}<0.001$ denoted by * and **, respectively

contrasts indicated that the sequential application of pendimethalin PPI followed by POST herbicides provided better control of $S$. arvensis compared to the pendimethalin PPI alone but did not improve control of $S$. arvensis compared to the POST herbicides alone.

\section{Setaria Viridis}

Pendimethalin applied PPI at $1080 \mathrm{~g}$ ai ha ${ }^{-1}$ provided excellent (94-98\%) control of $S$. viridis and reduced density $96 \%$ and dry weight $97 \%$ compared to the weedy check (Tables 5). Bentazon, fomesafen, bentazon plus fomesafen or halosulfuron applied POST provided poor control of S. viridis and did not reduce density or dry weight (Table 5). The sequential application of pendimethalin applied PPI followed by bentazon, fomesafen, bentazon plus fomesafen or halosulfuron applied POST controlled $S$. viridis as much as 94, 97, 94 , and $96 \%$, reduced density $88,96,95$, and $94 \%$ and reduced dry weight $83,94,89$, and $96 \%$, respectively (Table 4). Orthogonal contrasts indicated that the sequential application of pendimethalin PPI followed by POST herbicides did not generally provide a benefit in controlling $S$. viridis compared to pendimethalin PPI alone but provided better control of $S$. viridis compared to the POST herbicides alone.
In other studies, combination of graminicides with broadleaved herbicides has been shown to improve the level of weed control in dry bean [10]. The sequential application of ethalfluralin applied PPI followed by imazethapyr improved $S$. viridis, green smartweed (Polygonum scabrum (L.) Beauv.), wild buckwheat (Polygonum convolvulus L.), and hairy nightshade (Solanum sarrachoides Sendtner) control [10]. Blackshaw et al. [10] also found that combination of ethalfuralin with bentazon improved the control of $P$. convolvulus and $S$. sarrachoides. Other studies have shown that control of some grasses such as E. crus-galli increased from $58-96 \%$ to $98 \%$ when pendimethalin, EPTC, metolachlor, or trifluralin was applied PPI in combination with broadleaved herbicides such as imazerhapyr [12].

\section{White Bean Yield}

Weed interference in white bean with PPI application of pendimethalin at $1080 \mathrm{~g}$ ai ha ${ }^{-1}$, reduced yield of white bean $43-85 \%$ compared to the weed-free (Table 6). Weed interference with the POST application of bentazon, fomesafen, bentazon plus fomesafen or halosulfuron reduced white bean yield by $49-65,43-50,46-58$, and $49-85 \%$, respectively (Table 6). The sequential application of pendimethalin applied 
Table 3. Visual estimates of percent common lamb's-quarters control 4 and 8 WAA, density and dry weight with various herbicides in white bean at Exeter, ON from 2009 to 2011. Means followed by the same letter (a-h) within a column are not significantly different according to Fisher's Protected LSD at $\mathbf{P}<0.05$.

\begin{tabular}{|c|c|c|c|c|c|c|c|c|c|c|c|c|}
\hline \multirow{4}{*}{$\begin{array}{l}\text { Treatment } \\
\text { Weedy check }\end{array}$} & \multirow{2}{*}{\multicolumn{2}{|c|}{ Rate }} & \multicolumn{6}{|c|}{ Weed control } & & & & \\
\hline & & & \multirow{2}{*}{\multicolumn{2}{|c|}{4 WAA }} & \multicolumn{4}{|c|}{8 WAA } & & & & \\
\hline & PPI & POST & & & 20 & 09 & 201 & -11 & \multicolumn{2}{|c|}{$\begin{array}{c}\text { Density } \\
{\text { Plants } \mathbf{m}^{-2}}^{2}\end{array}$} & \multicolumn{2}{|c|}{$\begin{array}{c}\text { Dry weight } \\
\mathrm{g} \mathrm{m}^{-2}\end{array}$} \\
\hline & - & - & 0 & f & & $\mathrm{e}$ & & h & 26.5 & d & 42.4 & fg \\
\hline Weed-free check & - & - & 100 & $\mathrm{a}$ & 100 & $\mathrm{a}$ & 100 & $\mathrm{a}$ & & $\mathrm{a}$ & & a \\
\hline Bentazon & - & 1080 & 85 & $\mathrm{bc}$ & 90 & $a b$ & 86 & de & 2.7 & $\mathrm{~b}$ & 2.5 & $a b c$ \\
\hline Fomesafen & - & 240 & 55 & $\mathrm{~d}$ & 75 & $\mathrm{~cd}$ & 58 & $\mathrm{f}$ & 8.5 & $\mathrm{c}$ & 21.9 & def \\
\hline Bentazon + fomesafen & - & $840+140$ & 76 & $\mathrm{c}$ & 85 & $\mathrm{bc}$ & 80 & $\mathrm{e}$ & 4.1 & $\mathrm{bc}$ & 6.9 & $\mathrm{~cd}$ \\
\hline Halosulfuron & - & 35 & 26 & $\mathrm{e}$ & & e & 38 & $\mathrm{~g}$ & 31.7 & $\mathrm{~d}$ & 116.7 & $\mathrm{~g}$ \\
\hline $\begin{array}{l}\text { Pendimethalin fb } \\
\text { halosulfuron }^{\mathrm{c}}\end{array}$ & 1080 & 35 & 76 & $\mathrm{c}$ & & d & & $\mathrm{e}$ & 5.0 & $\mathrm{bc}$ & 27.2 & ef \\
\hline \multirow{2}{*}{ Contrasts } & \multicolumn{2}{|c|}{ PPI vs PPI fb POST } & \multicolumn{2}{|c|}{ NS } & \multicolumn{2}{|c|}{ NS } & & 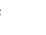 & \multicolumn{2}{|c|}{ NS } & \multicolumn{2}{|c|}{ * } \\
\hline & \multicolumn{2}{|c|}{ POST vs PPI fb POST } & \multicolumn{2}{|c|}{$* *$} & \multicolumn{2}{|c|}{$* *$} & \multicolumn{2}{|c|}{ ** } & \multicolumn{2}{|c|}{ * } & \multicolumn{2}{|c|}{ * } \\
\hline
\end{tabular}

Abbreviations: DAA, days after POST application; fb, followed by; NS, not significant; POST, postemergence; PPI, preplant incorporated.

Included Turbocharge at $0.5 \% \mathrm{v} / \mathrm{v}$.

Included non-ionic surfactant at $0.25 \% \mathrm{v} / \mathrm{v}$.

Significance at $\mathrm{P}<0.05$ and $\mathrm{P}<0.001$ denoted by $*$ and $* *$, respectively.

Table 4. Visual estimates of percent wild mustard control 4 and 8 WAA, density and dry weight with various herbicides in white bean at Exeter, ON from 2009 to 2011 . Means followed by the same letter (a-c) within a column are not significantly different according to Fisher's Protected LSD at $\mathbf{P}<0.05$.

\begin{tabular}{|c|c|c|c|c|c|c|c|c|c|c|}
\hline \multirow{3}{*}{ Treatment } & \multicolumn{2}{|c|}{ Rate } & \multicolumn{4}{|c|}{ Weed control } & & & & \\
\hline & PPI & POST & 4 WA & & 8 WA & & \multirow{2}{*}{\multicolumn{2}{|c|}{$\begin{array}{c}\text { Density } \\
\text { Plants } \mathbf{m}^{-2}\end{array}$}} & \multirow{2}{*}{\multicolumn{2}{|c|}{$\frac{\text { Dry weight }}{\mathrm{g} \mathrm{m}^{-2}}$}} \\
\hline & \multicolumn{2}{|c|}{ g ai ha ${ }^{-1}$} & \multicolumn{4}{|c|}{$\%$} & & & & \\
\hline Weed-free check & - & - & 100 & $\mathrm{a}$ & 100 & $\mathrm{a}$ & & $\mathrm{a}$ & & a \\
\hline Pendimethalin & 1080 & - & 23 & $\mathrm{~b}$ & 0 & $\mathrm{~b}$ & 9.0 & $\mathrm{~b}$ & 77.6 & $\mathrm{c}$ \\
\hline Fomesafen & - & 240 & 100 & $\mathrm{a}$ & 100 & $\mathrm{a}$ & & $\mathrm{a}$ & & $\mathrm{a}$ \\
\hline Bentazon + fomesafen & - & $840+140$ & 100 & $\mathrm{a}$ & 100 & a & & $\mathrm{a}$ & & $\mathrm{a}$ \\
\hline Halosulfuron & - & 35 & 100 & $\mathrm{a}$ & 100 & $\mathrm{a}$ & & $\mathrm{a}$ & & $\mathrm{a}$ \\
\hline Pendimethalin fb bentazon & 1080 & 1080 & 97 & $\mathrm{a}$ & 100 & a & 0.1 & $\mathrm{a}$ & 0.1 & a \\
\hline $\begin{array}{l}\text { Pendimethalin } \mathrm{fb} \\
\text { halosulfuron }^{\mathrm{c}}\end{array}$ & 1080 & 35 & 100 & $\mathrm{a}$ & 100 & $\mathrm{a}$ & & $\mathrm{a}$ & & $\mathrm{a}$ \\
\hline$C_{0}$ & \multicolumn{2}{|c|}{ PPI vs PPI fb POST } & \multicolumn{2}{|l|}{$* *$} & \multicolumn{2}{|l|}{$* *$} & \multicolumn{2}{|c|}{$* *$} & \multicolumn{2}{|c|}{$* *$} \\
\hline Contrasts & \multicolumn{2}{|c|}{ POST vs PPI fb POST } & \multicolumn{2}{|l|}{ NS } & \multicolumn{2}{|l|}{ NS } & \multicolumn{2}{|c|}{ NS } & \multicolumn{2}{|c|}{ NS } \\
\hline
\end{tabular}

Abbreviations: DAA, days after POST application; fb, followed by; NS, not significant; POST, postemergence; PPI, preplant incorporated

Included Turbocharge at $0.5 \% \mathrm{v} / \mathrm{v}$.

Included non-ionic surfactant at $0.25 \% \mathrm{v} / \mathrm{v}$.

Significance at $\mathrm{P}<0.05$ and $\mathrm{P}<0.001$ denoted by * and **, respectively. 
Table 5. Visual estimates of percent green foxtail control 4 and 8 WAA, density and dry weight with various herbicides in white bean at Exeter, ON from 2009 to 2011 . Means followed by the same letter (a-e) within a column are not significantly different according to Fisher's Protected LSD at $\mathbf{P}<0.05$.

\begin{tabular}{|c|c|c|c|c|c|c|c|c|c|c|c|c|}
\hline \multirow{4}{*}{ Treatment } & \multirow{2}{*}{\multicolumn{2}{|c|}{ Rate }} & \multicolumn{6}{|c|}{ Weed control } & & & & \\
\hline & & & \multicolumn{4}{|c|}{4 WAA } & & \multirow{3}{*}{\multicolumn{2}{|c|}{$\begin{array}{c}\text { Density } \\
\text { Plants } \mathbf{m}^{-2} \\
\end{array}$}} & & \\
\hline & PPI & POST & \multicolumn{2}{|c|}{2009} & \multicolumn{2}{|c|}{ 2010-11 } & & & & & \multirow{2}{*}{\multicolumn{2}{|c|}{$\begin{array}{c}\text { Dry weight } \\
\mathrm{g} \mathrm{m}^{-2}\end{array}$}} \\
\hline & \multicolumn{2}{|c|}{ g ai ha $^{-1}$} & \multicolumn{4}{|c|}{$\%$} & \multicolumn{2}{|c|}{8 WAA } & & & & \\
\hline Weedy check & - & - & & $\mathrm{e}$ & 0 & $\mathrm{e}$ & & $\mathrm{d}$ & 25.1 & $\mathrm{c}$ & 26.7 & $\mathrm{~b}$ \\
\hline Weed-free check & - & - & 100 & $\mathrm{a}$ & 100 & $\mathrm{a}$ & 100 & a & & $\mathrm{a}$ & 0.0 & a \\
\hline Pendimethalin & 1080 & - & 94 & $\mathrm{ab}$ & 98 & $a b$ & 96 & $\mathrm{~b}$ & 1.1 & $\mathrm{ab}$ & 0.8 & a \\
\hline Bentazon & - & 1080 & 0 & $\mathrm{e}$ & 0 & e & & d & 45.3 & $\mathrm{c}$ & 179.0 & c \\
\hline Fomesafen & - & 240 & 65 & $\mathrm{c}$ & 34 & d & 23 & c & 26.7 & $\mathrm{c}$ & 56.0 & $\mathrm{bc}$ \\
\hline Bentazon + fomesafen & - & $840+140$ & 48 & d & 0 & e & & d & 39.7 & $\mathrm{c}$ & 130.1 & c \\
\hline Halosulfuron & - & 35 & 1 & e & 0 & e & & d & 31.9 & $\mathrm{c}$ & 66.5 & $\mathrm{bc}$ \\
\hline Pendimethalin fb bentazon & 1080 & 1080 & 90 & $\mathrm{~b}$ & 94 & $\mathrm{bc}$ & 93 & $\mathrm{~b}$ & 3.0 & $\mathrm{~b}$ & 4.5 & a \\
\hline Pendimethalin $\mathrm{fb}$ fomesafen ${ }^{\mathrm{b}}$ & 1080 & 240 & 94 & $\mathrm{ab}$ & 94 & $\mathrm{bc}$ & 97 & $\mathrm{~b}$ & 0.9 & $\mathrm{ab}$ & 1.5 & a \\
\hline $\begin{array}{l}\text { Pendimethalin fb bentazon }+ \\
\text { fomesafen }\end{array}$ & 1080 & $840+140$ & 89 & $\mathrm{~b}$ & 93 & $\mathrm{c}$ & 94 & $b$ & 1.3 & $\mathrm{ab}$ & 3.0 & a \\
\hline $\begin{array}{l}\text { Pendimethalin fb } \\
\text { halosulfuron }^{c}\end{array}$ & 1080 & 35 & 96 & $a b$ & 94 & $\mathrm{bc}$ & 95 & $\mathrm{~b}$ & & $\mathrm{ab}$ & 1.1 & a \\
\hline Contrasts & PPI vs & $\mathrm{fb}$ POST & $\mathrm{N}$ & IS & $*$ & * & & vS & $\mathrm{N}$ & $\mathrm{S}$ & & vS \\
\hline Contrasts & POST vs & I fb POST & $*$ & $*$ & $* *$ & $*$ & & $*$ & $*$ & * & & $*$ \\
\hline
\end{tabular}

Abbreviations: DAA, days after POST application; fb, followed by; NS, not significant; POST, postemergence; PPI, preplant incorporated.

Included Turbocharge at $0.5 \% \mathrm{v} / \mathrm{v}$.

Included non-ionic surfactant at $0.25 \% \mathrm{v} / \mathrm{v}$.

Significance at $\mathrm{P}<0.05$ and $\mathrm{P}<0.001$ denoted by * and $* *$, respectively.

Table 6. White bean yield for various herbicide treatments at Exeter, ON from 2009 to 2011 . Means followed by the same letter (a-d) within a column are not significantly different according to Fisher's Protected LSD at $\mathbf{P}<0.05$.

\begin{tabular}{|c|c|c|c|c|c|c|}
\hline \multirow{3}{*}{ Treatment } & \multicolumn{2}{|c|}{ Rate } & \multicolumn{4}{|c|}{ Yield } \\
\hline & PPI & POST & & 009 & 2010 & -11 \\
\hline & \multicolumn{2}{|c|}{ g ai ha ${ }^{-1}$} & \multicolumn{4}{|c|}{ MT ha ${ }^{-1}$} \\
\hline Weed-free check & - & - & 2.6 & $\mathrm{a}$ & 3.5 & a \\
\hline Pendimethalin & 1080 & - & 0.4 & $\mathrm{~cd}$ & 2.0 & $\mathrm{bc}$ \\
\hline Fomesafen & - & 240 & 1.3 & $\mathrm{~b}$ & 2.0 & $\mathrm{bc}$ \\
\hline Bentazon + fomesafen & - & $840+140$ & 1.1 & $\mathrm{bc}$ & 1.9 & $\mathrm{bc}$ \\
\hline Halosulfuron & - & 35 & 0.4 & $\mathrm{~cd}$ & 1.8 & $\mathrm{c}$ \\
\hline Pendimethalin fb bentazon & 1080 & 1080 & 0.9 & bcd & 2.9 & $a b$ \\
\hline $\begin{array}{l}\text { Pendimethalin fb } \\
\text { halosulfuron }^{c}\end{array}$ & 1080 & 35 & & $\mathrm{~b}$ & 3.4 & $\mathrm{a}$ \\
\hline \multirow{2}{*}{ Contrasts } & \multicolumn{2}{|c|}{ PPI vs PPI fb POST } & & $*$ & \multicolumn{2}{|c|}{ * } \\
\hline & \multicolumn{2}{|c|}{ POST vs PPI fb POST } & & $*$ & \multicolumn{2}{|c|}{$* *$} \\
\hline
\end{tabular}

Abbreviations: DAA, days after POST application; fb, followed by; NS, not significant; POST, postemergence; PPI, preplant incorporated.

Included Turbocharge at $0.5 \% \mathrm{v} / \mathrm{v}$.

Included non-ionic surfactant at $0.25 \% \mathrm{v} / \mathrm{v}$.

Significance at $\mathrm{P}<0.05$ and $\mathrm{P}<0.001$ denoted by $*$ and $* *$, respectively.

PPI followed by the POST application of bentazon, fomesafen, bentazon plus fomesafen or halosulfuron reduced yield $65,38,38$, and $50 \%$ in 2009 , respectively but had no significant effect on the yield of white bean in 2010 and 2011 (Table 6). 
Other studies have shown yield losses of $40-71 \%$ in white bean [13,14] and $71-85 \%$ in pinto bean [15] when $A$. retroflexus and $C$. album were inadequately controlled. In other studies, yield of white bean was increased when graminicides such as dimethenamid-p was applied in combination with broadleaved herbicides such as imazethapyr in kidney bean $[7,12,16]$.

\section{CONCLUSIONS}

Based on this study, pendimethalin provided adequate control of $A$. retroflexus, C. album, and $S$. viridis and inadequate control of $A$. artemisiifolia and $S$. arvensis. Bentazon provided adequate control of $C$. album and S. arvensis, and inadequate control of A. artemisiifolia. A. retroflexus, and S.viridis. Fomesafen, bentazon plus fomesafen, or halosulfuron provided adequate control of $A$. retroflexus, A. artemisiifolia and S. arvensis and inadequate control of C. album and S.viridis. The sequential application of pendimethalin applied PPI followed by the POST application of bentazon, fomesafen, bentazon plus fomesafen, or halosulfuron generally provided adequate control of $A$. retroflexus, $A$. artemisiifolia, C. album, S. arvensis and S.viridis, however results were not always consistent for the control of $C$. album. Results also indicated that weed interference with the PPI application of pendimethalin, POST application of bentazon, fomesafen, bentazon plus fomesafen or halosulfuron, and the sequential application of pendimethalin PPI followed by the POST application of bentazon, fomesafen, bentazon plus fomesafen or halosulfuron have potential to reduce yield in white bean under some environments. However, there is potential for broad-spectrum weed control with the sequential application of pendimethalin applied PPI followed by bentazon, fomesafen, bentazon plus fomesafen or halosulfuron applied POST in white bean for specific weed species in some environments.

\section{ABBREVIATIONS}

$\begin{array}{ll}\mathrm{DAA} & =\text { Days after POST application } \\ \mathrm{fb} & =\text { Followed by } \\ \mathrm{NS} & =\text { Not significant } \\ \mathrm{POST} & =\text { Postemergence } \\ \mathrm{PPI} & =\text { Preplant incorporated }\end{array}$

\section{CONFLICT OF INTEREST}

\section{ACKNOWLEDGEMENTS}

The authors would like to acknowledge Todd Cowan for his expertise and technical assistance in these studies. Funding for this project was provided by the Ontario White Bean Producers and the Agricultural Adaptation Council.

\section{REFERENCES}

[1] Breuer T. The Emerging Bean, Harvest (2002 ed), Ontario White Bean Producers. London, ON, Canada. 2002; p. 16.

[2] McGee B. Estimated Area, Yield, Production and Farm Value of Specified Field Crops, Ontario, 2001-2011; 2012. http://www.omafra.gov.on.ca /english/stats/crops/estimate_metric.htm

[3] Chikoye D, Weise SF, Swanton CJ. Influence of common ragweed (Ambrosia artemisiifolia) time of emergence and density on white bean (Phaseolus vulgaris). Weed Sci 1995; 43: 375-80.

[4] Malik VS, Swanton CJ, Michaels TE. Interaction of white bean (Phaseolus vulgaris) cultivars, row spacing, and seeding density with annual weeds. Weed Sci 1993; 41: 62-8.

[5] Bauer TA, Renner KA, Penner D, Kelly JD. Pinto bean (Phaseolus vulgaris) varietal tolerance to imazethapyr. Weed Sci 1995; 43: 417-24.

[6] Burnside OC, Ahrens WH, Holder BJ, Wiens MJ, Johnson MM, Ristau EA. Efficacy and economics of various mechanical plus chemical weed control systems in dry bean (Phaseolus vulgaris). Weed Technol 1994; 8: 238-44.

[7] Urwin CP, Wilson RG, Mortensen DA. Responses of dry edible bean (Phaseolus vulgaris) cultivars to four herbicides. Weed Technol 1999; 10: 512-8.

[8] (OMAFRA) Ontario Ministry of Agriculture, Food and Rural Affairs. Guide to weed control. Publication 75, Toronto, ON, Canada, OMAFRA 2011; p. 348.

[9] Senseman SA. Herbicide Handbook," ( $9^{\text {th }}$ ed). Champaign, IL: Weed Sci Soc Am 2007; p. 458.

[10] Blackshaw RE, Molnar LJ, Muendel HH, Saindon G, Li X. Integration of cropping practices and herbicide improves weed management in dry bean (Phaseolus vulgaris). Weed Technol 2000; 14: 327-36.

[11] Statistical Analysis Systems. The SAS System for Windows, Release 9.2. Cary, NC: Statistical Analysis Systems Institute 2008; p. 3884.

[12] Arnold NR, Murray WM, Gregory JE, Smeal D. Weed control in pinto beans (Phaseolus vulgaris) with imazethapyr combinations. Weed Technol 1993; 7: 361-4.

[13] Blackshaw RE, Saindon G. Dry bean (Phaseolus vulgaris) tolerance to imazethapyr. Can J Plant Sci 1996; 76: 915-9.

[14] Wall DA. Bentazon tank mixtures for control of redroot pigweed and common lambsquarters in navy bean. Weed Technol 1995; 9: 610-6.

[15] Blackshaw RE, Esau R. Control of annual broadleaf weeds in pinto beans (Phaseolus vulgaris). Weed Technol 1991; 5: 532-8.

[16] Soltani N, Van Eerd LL, Vyn RJ, Shropshire C, Sikkema PH. Weed management in dry bean (Phaseolus vulgaris) with dimethenamid plus reduced doses of imazethapyr applied preplant incorporated. Crop Prot 2007; 26: 739-45. 